\title{
Oral zinc supplementation restore high molecular weight seminal zinc binding protein to normal value in Iraqi infertile men
}

\author{
Mahmoud Hussein Hadwan ${ }^{1 *}$, Lamia A Almashhedy ${ }^{1}$ and Abdul Razzaq S Alsalman²
}

\begin{abstract}
Background: Zinc in human seminal plasma is divided into three types of ligands which are high (HMW), intermediate (IMW), and low molecular weight ligands (LMW). The present study was aimed to study the effect of Zn supplementation on the quantitative and qualitative characteristics of semen along with Zinc Binding Protein levels in the seminal plasma in asthenozoospermic patients.

Methods: Semen samples were obtained from 37 fertile and 37 asthenozoospermic infertile men with matched age. The subfertile group was treated with zinc sulfate, every participant took two capsules per day for three months (each one 220mg). Semen samples were obtained (before and after zinc sulfate supplementation). After liquefaction seminal fluid at room temperature, routine semen analyses were performed. For determination of the amount of zinc binding proteins, the gel filtration of seminal plasma on Sephadex G-75 was performed. All the fractions were investigated for protein and for zinc concentration by atomic absorption spectrophotometry. Evaluation of chromatograms was made directly from the zinc concentration in each fraction.
\end{abstract}

Results: A significant high molecular weight zinc binding ligands percentage (HMW-Zn \%) was observed in seminal plasma of fertile males compared with subfertile males. However, seminal low molecular weight ligands (LMW-Zn) have opposite behavior. The mean value of semen volume, progressive sperm motility percentage and total normal sperm count were increased after zinc sulfate supplementation.

Conclusions: Zinc supplementation restores HMW-Zn\% in seminal plasma of asthenozoospermic subjects to normal value. Zinc supplementation elevates $L M W-Z n \%$ in seminal plasma of asthenozoospermic subjects to more than normal value.

Trial registration: ClinicalTrials.gov identifier NCT01612403

Keywords: Zinc, Zinc binding protein, Gel filtration, Asthenozoospermia, Semenogelin

\section{Background}

Infertility is defined as lack of ability to conceive within one year of unprotected intercourse with the same partner [1]. It is estimated that nearly $8--12 \%$ of couples are infertile [2]. There are several causes leading to male infertility, like radiation, cigarette smoking, varicocele, antibacterial drugs, infections, obstructive lesions, therapeutic drugs, trauma, genitourinary infection, environmental agents, oxidative stress, and nutritional deficiency of trace elements like, selenium and zinc $[3,4]$. $\mathrm{Zn}$ is the following

\footnotetext{
* Correspondence: mahmoudhadwan@gmail.com

'Chemistry Department, College of Science, Babylon University, Hillah, Iraq Full list of author information is available at the end of the article
}

only to iron as the most abundant element in the body. Although, Zinc is found in red meat, white meat, fish, and milk; the World Health Organization (WHO) approximates that one-third of world population is deficient in $\mathrm{Zn}$ [5]. Zinc and citrate are excreted from the prostate gland as a low molecular weight complex, for that explanation, it is estimated that zinc levels in seminal plasma typically represent the prostatic secretory function. After ejaculation, halve quantity of this complex is redistributed and linkage to medium and high molecular weight compounds which generated from the seminal vesicles [6]. $\mathrm{Zn}$ is vital to reproductive potential. It has been reported to protect sperm from bacteria and chromosomes damage [7]. Also,
Ciomed Central

(c) 2012 Hadwan et al.; licensee BioMed Central Ltd. This is an Open Access article distributed under the terms of the Creative Commons Attribution License (http://creativecommons.org/licenses/by/2.0), which permits unrestricted use, distribution, and reproduction in any medium, provided the original work is properly cited. 
it plays a central role in normal testicular growth, spermatogenesis, and sperm physiology [8]; it conserves genomic integrity in the sperm and stabilizes connection of sperm head to tail [9]. Deficiency of $\mathrm{Zn}$ is associated with hypogonadism and insufficient growth of secondary sex characteristics in human beings [10]. Low seminal $\mathrm{Zn}$ levels were coupled with a decrease in fertilizing ability of sperm [11] and decreased the synthesis of testosterone $[12,13]$. Also, it can cause atrophy of the seminiferous tubules in the rat, and that leads to malfunction in spermatogenesis and impotence [14].

The binding of zinc with some proteins, such as metallothioneins $[\mathrm{MT}]$ and $\alpha-2$ macroglobulin $[\alpha-2 \mathrm{M}]$ is fundamental immune efficiency for the duration of ageing and in age-related diseases. These proteins may turn from a function of protection against cellular oxidative injury. Furthermore, zinc-binding proteins regain their essential role of cellular protection against oxidative damage after zinc supplementation [15].

Studies have shown that oral zinc supplementation develops sperm count, motility and the physical characteristics of sperm in animals $[16,17]$ and also, in some groups of infertile men $[18,19]$. The present study was conducted to study the effect of $\mathrm{Zn}$ supplementation on the quantitative and qualitative characteristics of semen along with Zinc Binding Protein levels in the seminal plasma of asthenozoospermic patients.

\section{Methods}

\section{Patients}

This study includes 37 subfertile male partners between July 2011 to April 2012, from couples who had consulted the infertility clinic of the Babil hospital of maternity (Hilla city/IRAQ). The approval of the institutional research ethics committee, and consent of every patient included in the study was obtained. A detailed medical history was taken and physical examination was performed. Subjects currently on any medication or antioxidant supplementation were not included. The inclusion criteria were asthenozoospermia, the absence of endocrinopathy, varicocele, and female factor infertility. Smokers and alcoholic men were excluded from the study because of their recognized high seminal ROS levels and decreased antioxidant levels. The selection criteria of fertile group were the absence of asthenozoospermia, endocrinopathy, varicocele, and have a birth in the last year.

\section{Semen analysis}

Semen samples were obtained from 37 fertile (age 31.4 \pm 4.2 year) and 37 subfertile (age $32.3 \pm 3.68$ year) men with asthenozoospermia by masturbation after three days of sexual abstinence. The subfertile group was treated with zinc sulfate, every participant took two capsules of zinc sulfate per day for three months (each one 220mg). Semen samples were obtained (before and after zinc sulfate supplementation). After liquefaction seminal fluid at room temperature, routine semen analyses including semen volume, $\mathrm{pH}$, concentration, sperm motility, normal sperm morphology and round cell were performed according to 2010 WHO recommendation [20].

An aliquot of the remaining semen was centrifuged at $2000 \mathrm{~g}$ for $15 \mathrm{~min}$ and the seminal plasma was collected immediately. These fractions were classified into three groups called group I (healthy donors), group II (patients before treatment) and group III (patients after treatment) respectively. After that, the samples were frozen $\left(-20^{\circ} \mathrm{C}\right)$ until analyzed.

\section{Chemicals}

All reagents and chemicals were of analytical grade and obtained from standard commercial suppliers.

\section{Biochemical procedures \\ Gel filtration}

For determination of the amount of zinc binding proteins, the gel filtration of seminal plasma on Sephadex G-75 was performed according to Arver method exactly [21]. Sephadex G-75 was packed in a $2.5 \times 40 \mathrm{~cm}$ glass column and equilibrated and eluted with $0.05 \mathrm{M}$ Tris buffer containing $0.15 \mathrm{M} \mathrm{NaCl}, \mathrm{pH}$ 7.4. The elution was collected at a flow rate of $10-16 \mathrm{ml} \mathrm{cm}^{-2} \mathrm{~h}^{-1}$ in 50 fractions. All the fractions were investigated for protein (A 280nm) and for zinc concentration by atomic absorption spectrophotometry (shimadzu AA 6300). Homogeneity of gel packing and void volume $\left(\mathrm{V}_{\mathrm{o}}\right)$ was checked with Dextrane Blue 2000 (Pharmacia, Sweden). Total column volume was calculated from column dimensions. Evaluation of chromatograms were made directly from the zinc concentration in each fraction and the peaks were referred to as I, II, and III or HMW, IMW and LMW (High, Intermediate and Low molecular Weight zinc binding protein) respectively. The area of peak was calculated by Simpson's 1/3 rule [22].

\section{Statistical analysis}

Student's $t$ and the Mann-Whitney $U$-tests were used for statistical analyses.

\section{Ethical committee \\ Iraq: Ethics Committee}

\section{Results}

The results in Table (1) indicate the baseline, characteristics of the semen parameters are depicted in the fertile and subfertile (before and after treatment with zinc sulfate) groups. These parameters were significantly decreased in infertile group compared with healthy donors group. However, the 
Table 1 Ejaculates parameters

\begin{tabular}{lllll}
\hline & $\begin{array}{l}\text { Semen volume } \\
(\mathrm{ml})\end{array}$ & $\begin{array}{l}\text { Sperm count } \\
\left(\times 10^{6}\right)\end{array}$ & $\begin{array}{l}\text { Progressive sperm } \\
\text { motility (\%) }\end{array}$ & $\begin{array}{l}\text { Normal sperm } \\
\text { form (\%) }\end{array}$ \\
\hline Healthy donors & $2.8 \pm 0.43$ & $83 \pm 16$ & $68 \pm 12$ & $77 \pm 5$ \\
\hline Patients before treatment & $1.72 \pm 0.66^{*}$ & $68 \pm 17^{*}$ & $22 \pm 7^{*}$ & $66 \pm 12$ \\
\hline Patients after treatment & $2.38 \pm 0.6^{* *}$ & $70 \pm 17$ & $38 \pm 8^{* *}$ & $71 \pm 8^{* *}$ \\
\hline
\end{tabular}

Sn $1 *$ : significance versus group I (Healthy donors).

$\mathrm{Sn} 2$ **: significance versus group II (Patients before treatment).

level of the semen parameters were significantly increased (return to normal value) after zinc sulfate supplementation.

The common appearance of the zinc distribution between different ligands in human seminal plasma as discovered by gel filtration on Sephadex G-75 is demonstrated in Figure 1. The HMW (peak I) and LMW (peak III) ligands have characteristic chromatographic properties but the IMW ligands (peak II) show an inconsistent pattern [21].

We observed a significant higher semen high molecular weight zinc binding ligands percentage (HMW-Zn \%) in fertile males compared with subfertile males; however, zinc supplementation restores this percentage in the subfertile men to the normal ranges. On the other hand, seminal low molecular weight ligands (LMW-Zn) have opposite behavior. IMW - Zn\% decreased significantly in semen of patients of asthenozoospermia.

\section{Discussion}

The concentration of zinc in human seminal plasma is higher than blood and tissues [23]. Zinc is part of copper -zinc superoxide dismutase and several proteins involved in the cell differentiation (eg, glycoprotein IIb/IIIa) as well as the factors activation such as KS-1, WT-1, Finb, TRAF-2, and ZEB [24-26]. Zinc deficiency affects reproduction adversely in view of the fact that all the hormones and a wide range of enzymes involved in reproduction are receptive to zinc. Principally, zinc is

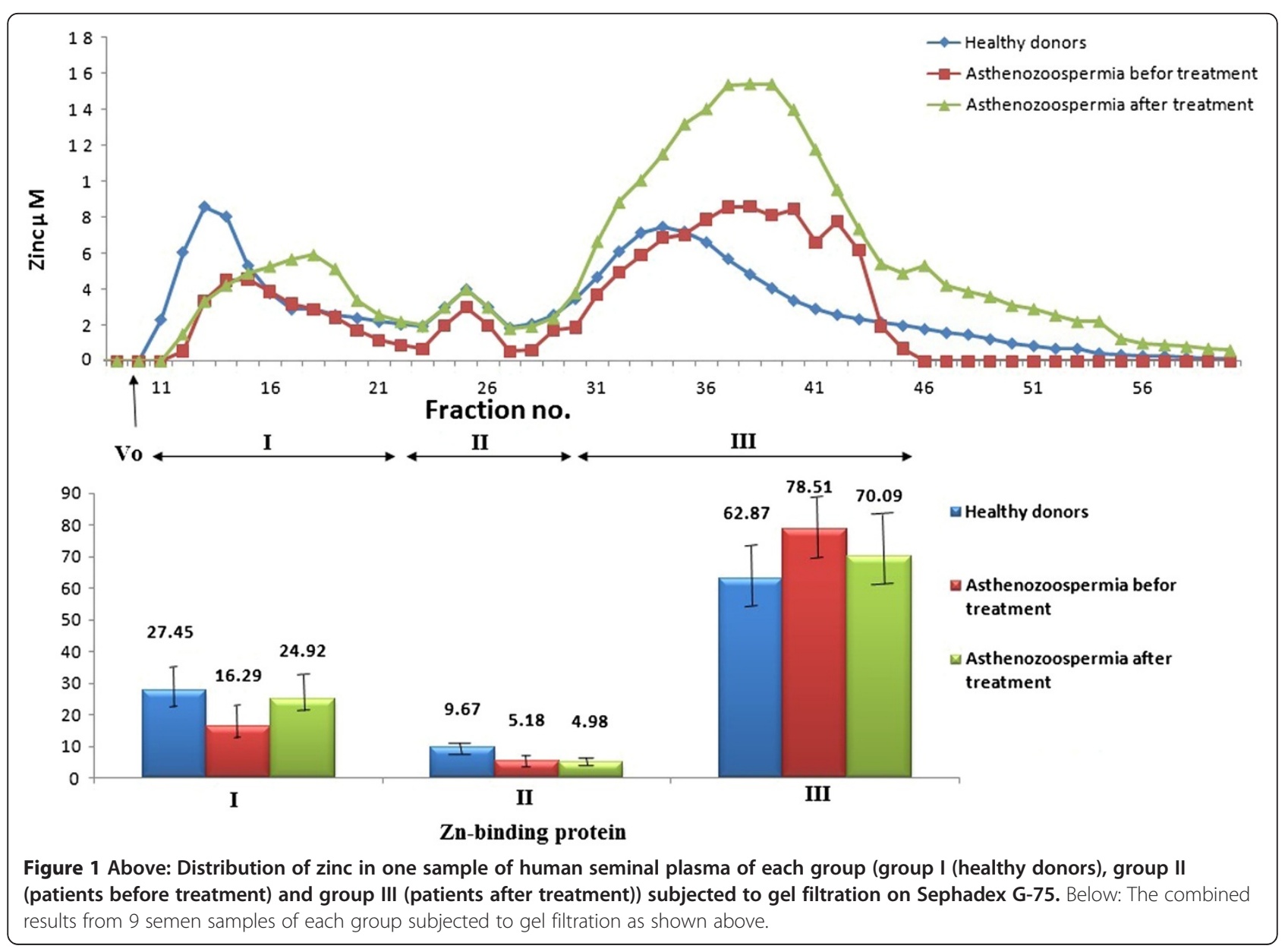


required for the synthesis and secretion of luteinizing hormones and follicle-stimulating hormone [27].

There have been conflicting clinical reports on the effect of seminal zinc on sperm count, motility and the physical characteristics of sperm. Several studies have pointed out that there are no significant difference between $\mathrm{Zn}$ levels in fertile and infertile men [28-31] but furthers found a significant difference between them [32-34]. Danscher et al. [35] indicated a high concentration of $\mathrm{Zn}$ to be linked with poor motility of sperm. Also, Carpino et al. [36] have reported high sperm zinc content to be associated with oligoasthenozoospermic specimens. On the other hand, others have observed a high zinc content in seminal plasma to be correlated with good physical characteristics of sperm such as sperm count [31,32], motility [33,37], and normal morphology [33,38].

As a result, total seminal zinc concentration may not be a useful indicator of the zinc fraction associated with physical characteristics of sperm and a more appropriate marker of the ion bioavailability should be utilized to assess its relationship to sperm functions. The best proof is zinc binding protein because all the previous studies as well as this study observed that zinc binding protein correlated with sperm functions such as count and motility $[28,33]$.

Seminal zinc has been investigated by measuring the amount of zinc bound to vesicular high, intermediate and low molecular weight protein. HMW-Zn\% was decreased in asthenozoospermic subjects. While, low zinc binding protein LMW-Zn\% exhibits reverse behavior, so it decreased in healthy fertile men and increased in subfertile.

The mechanism by which HMW-Zn\% in seminal plasma of asthenozoospermic subjects is depleted has not been fully explained in previous studies. Different studies have shown that $\mathrm{Zn}$ has an important role in scavenging reactive oxygen species (ROS) owing to it has antioxidative properties [39-41]. Elevated levels of ROS were detected in the semen of high percentage of infertile patients, which affected sperm function [42]. As a result, to this elevation of ROS levels, $\mathrm{Zn}$ levels may be reduced in seminal plasma of asthenozoospermic subjects, and that leads to an increase in oxidation of HMW-Zn binding proteins in seminal plasma. The last processes are associated with abnormal sperm parameters. Zinc supplementation restores HMW-Zn\% in seminal plasma of asthenozoospermic subjects to normal value, may be because its role in polymeric organization of macromolecules likes protein synthesis and cell division [43] or because its ability to influence the process of spermatogenesis and maintains the ability of sperm nuclear chromatin to undergo de-condensation and modulates sperm functions [44].

LMW-Zn\% is elevated in seminal plasma of asthenozoospermic patients may be because increment the levels of semenogelin in seminal plasma of asthenozoospermic subjects. Martinez-Heredia et al. [45] used 2DE-MS to recognize 17 protein spots with differential expression levels between asthenozoospermic samples and controls. Markedly, semenogelin has been shown to elevate in asthenozoospermic samples. Zhao et al. [46] demonstrated that semenogelin I precursor is recognized as four kinds of protein. Two of these proteins characterized $14 \mathrm{kDa}$ fragments and the other two were $17 \mathrm{kDa}$ fragments. All of these proteins were highly expressed in asthenozoospermic patients. Before this scientific finding, Yoshida et al. [47] documented that a $14 \mathrm{kDa}$ fragment of semenogelin has an inhibitory consequence on ejaculated spermatozoa. Semenogelin is secreted from the seminal vesicle at ejaculation and establish major structural components of coagulated human semen. It is defined as a sperm motility inhibitor, which is classified into two types of intermediate molecular weight zinc binding protein (IMW-ZnBP), [because it has molecular weight more than 3000 and less than 80 000], the first Semenogelin I (a protein of molecular weight (MW) 52 $\mathrm{kDa}$ ) and Semenogelin II (existed as two forms of a Sg Irelated protein with MWs of 71 and $76 \mathrm{kDa})[48,49]$. After

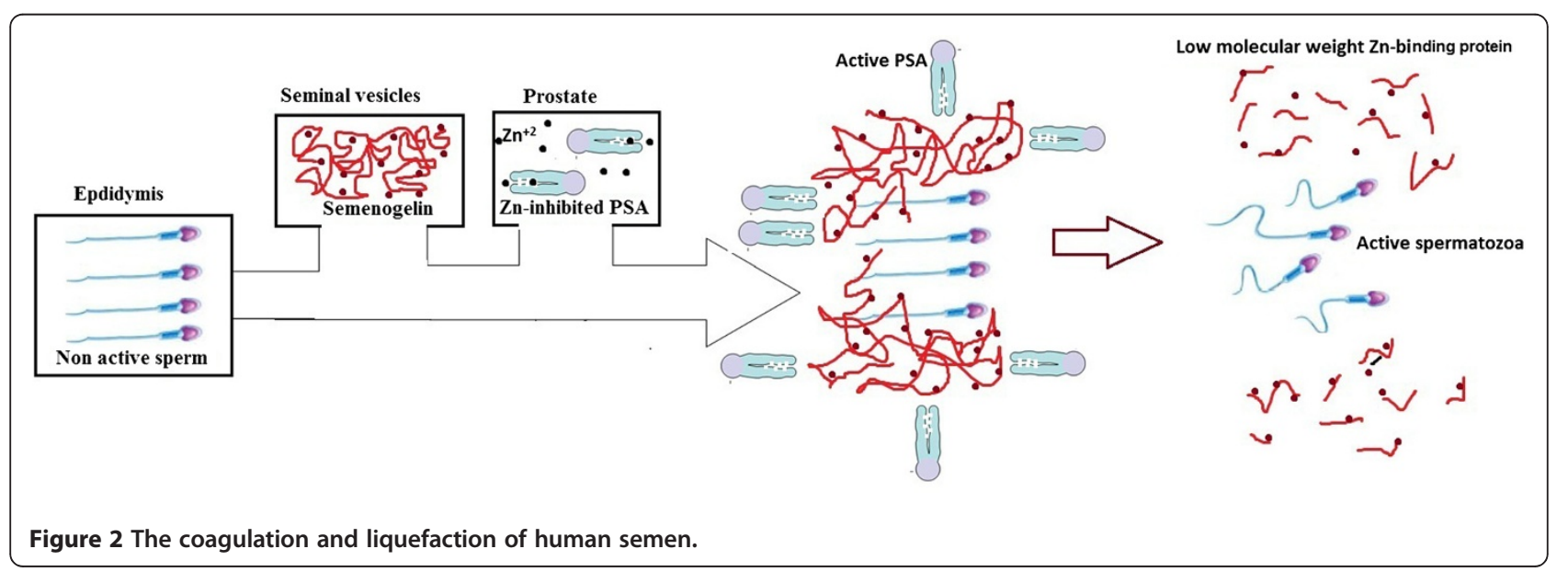


ejaculation, serine proteases, primarily prostate-specific antigen (PSA) act to cleave SgI and SgII molecules (intermediate molecular weight zinc binding protein IMW$\mathrm{ZnBP}$ ) to produce soluble fragments (Low molecular weight zinc binding protein LMW-ZnBP) [50]. PSA is accumulated in the prostate in a $\mathrm{Zn}^{2+}$-inhibited type. However, PSA is activated after mixing with Semenogelin, which has a higher $\mathrm{Zn}^{2+}$-binding affinity than PSA [51]. In corresponding to this liquefaction, the spermatozoa become regularly more motile, as shown in Figure 2.

Zinc supplementation elevates LMW-Zn\% in seminal plasma of asthenozoospermic subjects to more than normal value, that's may be because its enhancement the synthesis of metallothioneins (Low molecular weight zinc binding protein) [52,53]. The increment of LMW-Zn\% not coming from the degradation of semenogelin because $\mathrm{Zn}^{2+}$ acts to inhibit the protease activity of prostatespecific antigen [54]. The increment of LMW-Zn\% after supplementation is not harmful to spermatozoa because it's not generating from the degradation of semenogelin, i.e. it's not contain $14 \mathrm{kDa}$ fragment of semenogelin which has an inhibitory effect on ejaculated spermatozoa.

\section{Conclusions}

Zinc supplementation restores HMW-Zn\% in seminal plasma of asthenozoospermic subjects to normal value. Zinc supplementation elevates LMW-Zn\% in seminal plasma of asthenozoospermic subjects to more than normal value.

\section{Abbreviations}

ROS: Reactive Oxygen Species; SOD: Superoxide Dismutase; Zn: Zinc; AAS: Atomic Absorption Spectroscopy; WHO: World Health Organization; HMW: High molecular weight zinc binding protein; IMW: Intermediate molecular weight zinc binding protein; LMW: Low molecular weight zinc binding protein.

\section{Competing interests}

The authors declare that they have no competing interests.

\section{Authors' contributions}

All the authors made important roles to the design and viewing of the study. Principally, MHH wrote the manuscript, contributed to the investigation and elucidation of the data. LAA participated in its design and coordination and assisted to draft the manuscript. ARA contributed to the implementation of the protocol. All the authors have been involved in drafting and revising the manuscript, have read, and approved the final manuscript.

\section{Acknowledgements}

We want to thank Mr. Ahmed Sadoon (Research Laboratory of Trace elements, Chemistry Department, College of Science, Babylon University, Hilla, Iraq) for his help and assistance during chemical analysis.

\section{Author details \\ ${ }^{1}$ Chemistry Department, College of Science, Babylon University, Hillah, Iraq. ${ }^{2}$ Surgery Department, College of Medicine, Babylon University, Hillah, Iraq.}

Received: 27 May 2012 Accepted: 9 November 2012

Published: 13 November 2012

\section{References}

1. Brugh VM, Lipshultz LI: Male factor infertility: evaluation and management. Med Clin North Am 2004, 88:367-385.

2. Barbara B: Men contribute to and suffer from infertility. Family Health International 2003, 23:17-20.

3. Wong WY, Thomas CM, Merkus JM, Zielhuis GA, Steegers-Theunissen RP: Male factor sub-fertility: Possible causes and the impact of nutritional factors. Fertil Steril 2000, 73:435-442.

4. Olayemi FO: A review on some causes of male infertility. Afr J Biotechnol 2010, 9:2834-2842.

5. Khan MS, Zaman S, Sajjad M, Shoaib M, Gilani G: Assessment of the level of trace element zinc in seminal plasma of males and evaluation of its role in male infertility. Int J App Basic Med Res 2011, 1:93-96.

6. Mandal A, Bhattacharyya AK: Biochemical composition of washed human seminal coagulum in comparison to sperm --free semen from the same donors. J Reprod Fertil 1990, 88:113-118.

7. Judith EB: Nutrition through life cycle. 3rd edition. St. Paul, Minnesota: Brooks/Cole publishing company; 2008.

8. Elgazar V, Razanov V, Stoltenberg M, Hershfinkel M, Huleihel M, Nitzan YB, Lunenfeld E, Sekler I, Silverman WF: Zinc-regulating proteins, ZnT-1, and metallothionein $\mathrm{I} / \mathrm{Il}$ are present in different cell populations in the mouse testis. J Histochem Cytochem 2005, 53:905-912.

9. Tuerk MJ, Fazel N: Zinc deficiency. Curr Opin Gastroenterol 2009, 25(2):136-143.

10. Sandstorm B, Sandberg AS: Inhibitory affects of isolated inositol phosphates on zinc absorption in humans. J Trace Elem Electrolytes Health Dis 1992, 6:99-103.

11. Pandy VK, Parmeshwaran M, Soman SD, Dacosta JC: Concentrations of morphologically normal, motile spermatozoa: $\mathrm{Mg}^{+2}, \mathrm{Ca}^{+2}$ and $\mathrm{Zn}^{+2}$ in semen of infertile men. Sci Total Environ 1983, 27:49-52.

12. Ebisch IMW, Thomas CMG, Peters WHM, Braat DDM, Steegers-Theunissen RPM: The importance of folate, zinc and antioxidants in the pathogenesis and prevention of subfertility. Hum Reprod Update 2007, 13:163-174.

13. Prasad AS: Discovery of human zinc deficiency and studies in an experimental human model. Am J Clin Nutr 1991, 53:403-412.

14. Sandstead HH, Prasad AS, Schulert AR, Farid Z: Human zinc deficiency, endocrine manifestation and response to treatment. Am J Clin Nutr 1967, 20:422-442.

15. Mocchegiani E, Costarelli L, Giacconi R, Cipriano C, Muti E, Malavolta M: Zinc-binding proteins (metallothionein and a-2 macroglobulin) and Immunosenescence. Exp Gerontol 2006, 41:1094-1107.

16. Ghasemi N, Babaei H, Azizallahi S, Kheradmand A: Effect of long-term administration of zinc after scrotal heating on mice spermatozoa and subsequent offspring quality. Andrologia 2009, 41:222-228.

17. Rafique M, Naqvi A, Nankani K: Zinc improves the quality of semen albino rats. Medical channel 2010, 16:619-622.

18. Ebisch IMW, Pierik FH, De Jong FH, Thomas CMG, Steegers-Theunissen RPM: Does folic acid and zinc sulphate intervention affect endocrine parameters and sperm characteristics in men? Int J Androl 2006, 29:339-345.

19. Wong WY, Merkus HM, Thomas CM, Menkveld R, Zielhuis GA, SteegersTheunissen RP: Effects of folic acid and zinc sulfate on male factor subfertility: a double-blind, randomized, placebo-controlled trial. Fertil Steril 2002, 77:491-498.

20. World Health Organization: WHO laboratory manual for the examination and processing of human semen. 5th edition. Geneva, Switzerland: World Health Organization; 2010.

21. Arver S: Zinc and zinc ligands in human seminal plasma. I. Methodological aspects and normal findings. Int J Andrology 1980, 3:629-642.

22. Hoffman JD: Numerical methods for engineers and scientists revised and expanded. Second Editionthth edition. New York: MARCEL DEKKER, INC; 2001:293-295.

23. Sorensen MB, Stoltenberg M, Danscher G, Ernst E: Chelating of intracellular zinc ions affects human sperm cell motility. Mol Hum Reprod 1999, 5:338-441.

24. Saleh RA, Agarwal A, Sharma RK, Nelson DR, Thomas AJ: Effect of cigarette smoking on levels of seminal oxidative stress in infertile men. Fertil Steril 2002, 78:491-499.

25. Allen S, Badarau A, Dennison C: $\mathrm{Cu}(\mathrm{I})$ affinities of the domain 1 and 3 sites in the human metallochaperone for $\mathrm{Cu}, \mathrm{Zn}$-superoxide dismutase. Biochemistry 2012, 51:1439-1448. 
26. Mocchegiani E, Giacconi R, Muti E, Muzzioli M, Cipriano C: Zinc-binding proteins (metallothionein and $a-2$ macroglobulin) as potential biological markers of Immunosenescence. Neurolmmune Biology 2005, 4:23-40.

27. Jalali GR, Roozbeh J, Mohammadzadeh A, Sharifian M, Sagheb MM, Hamidian Jahromi A, Shabani S, Ghaffarpasand F, Afshariani R: Impact of oral zinc therapy on the level of sex hormones in male patients on hemodialysis. Ren Fail 2010, 32:417-426.

28. Abdul-Rasheed OF: The relationship between seminal plasma zinc levels and high molecular weight zinc binding protein and sperm motility in Iraqi infertile men. Saudi Med J 2009, 30:485-489.

29. Wong WY, Flik G, Groenen PM, Swinkels DW, Thomas CM, CopiusPeereboom JH, Merkus HM, Steegers-Theunissen RP: The impact of calcium, magnesium, zinc, and copper in blood and seminal plasma on semen parameters in men. Reprod Toxicol 2001, 15:131-136.

30. Bakalczuk S, Robak-Cholubek D, Jakiel G, Krasucki W: Level of zinc and magnesium in semen taken from male partners of married infertile couples. Ginekol Pol 1994, 65:67-70.

31. Fuse H, Kazama T, Ohta S, Fujiuchi Y: Relationship between zinc concentrations in seminal plasma and various sperm parameters. Int Urol Nephrol 1999, 31:401-408.

32. Mankad M, Sathawara NG, Doshi H, Saiyed HN, Kumar S: Seminal plasma zinc concentration and a-glucosidase activity with respect to semen quality. Biol Trace Elem Res 2006, 110:97-106.

33. Chia SE, Ong C, Chua L, Ho L, Tay S: Comparison of zinc concentration in blood and seminal plasma and various sperm parameters between fertile and infertile men. J Androl 2000, 21:53-57.

34. Yuyan L, Junqing W, Wei $Y$, Weijin Z, Ersheng G: Are serum zinc and copper levels related to semen quality? Fertil Steril 2008, 89:1008-1011.

35. Danscher G, Hammen R, Fjerdingstad E, Rebbe H: Zinc content of human ejaculate and the motility of sperm cells. Int J Androl 1978, 1:576-581.

36. Carpino A, Siciliano L, Petroni MF, De Stefano C, Aquila S, Ando S, et al: Low seminal zinc bound to high molecular weight proteins in asthenozoospermic patients: evidence of increased sperm zinc content in oligoasthenozoospermic patients. Hum Reprod 1998, 13:111-114.

37. Stankovic H, Mikac-Devic D: Zinc and copper in human semen. Clin Chim Acta 1976, 70:123-126.

38. Edorh AP, Tachev K, Hadou T, Gbeassor M, Sanni A, Creppy EE, Le Faou A, Rihn BH: Magnesium content in seminal fluid as an indicator of chronic prostitutes. Cell Mol Biol 2003, 49:419-423.

39. Oteiza PI, Olin KL, Fraga CG, Keen CL: Zinc deficiency causes oxidative damage to proteins, lipids and DNA in rat testes. J Nutr 1995, 125:823-829.

40. Gavella M, Lipovac V: In vitro effect of zinc on oxidative changes in human semen. Andrologia 1988, 30:317-323.

41. Bagchi D, Vuchetich PJ, Bagchi M, Tran MX, Krohn RL, Ray SD, Stohs SJ: Protective effects of zinc salts on TPA-induced hepatic and brain lipid peroxidation, glutathione depletion, DNA damage and peritoneal macrophage activation in mice. Gen Pharmacol 1998, 30:43-50.

42. Padron OF, Brackett NL, Sharma RK, Lynne CM, Thomas AJ, Agarwal A: Seminal reactive oxygen species, sperm motility, and morphology in men with spinal cord injury. Fertil Steril 1997, 67:1115-1120.

43. Ebisch IM, Van Heerde WL, Thomos CM, van der Put N, Wong WY, SteegersTheunissen RP: C677T methylene tetrahydrofolate reductase polymorphism interfere with effect of folic acid and zinc sulphate on sperm concentration. Fertil Steril 2003, 80:1190-1194.

44. Eggert Kruss W, Zwick EM, Batschulat K, Rohr G, Armbruster FP, Petzoldt D, Strowitzki T: Are zinc levels in seminal Effect of zinc supplementation on semen quality plasma associated with seminal leukocyte and other determinant of semen quality? Fertil Steril 2002, 17:260-269.

45. Martinez-Heredia J, de Mateo S, Vidal-Taboada JM, Ballesca JL, Oliva R: Identification of proteomic differences in asthenozoospermic sperm samples. Hum Reprod 2008, 23:783-791.

46. Zhao C, Huo R, Wang FQ, Lin M, Zhou ZM, Sha JH: Identification of several proteins involved in regulation of sperm motility by proteomic analysis. Fertil Steril 2007, 87:436-438.

47. Yoshida K, Yamasaki T, Yoshiike M, Takano S, Sato I, Iwamoto T: Quantification of seminal plasma motility inhibitor/semenogelin in human seminal plasma. J Androl 2003, 24:878-884.

48. Chaistitvanich $\mathrm{N}$, Boonsaeng $\mathrm{V}$ : Molecular structure of human seminal coagulum: the role of disulfide bonds. Andrologia 1983, 15:446-451.

49. Lilja $H$, Laurell CB: The predominant protein in human seminal coagulates. Scand J Clin Lab Invest 1985, 45:635-641.
50. Lilja $\mathrm{H}$ : A kallikrein-like serine protease in prostatic fluid cleaves the predominant seminal vesicle protein. J Clin Invest 1985, 76:1899-1903.

51. Jonsson M, Linse S, Frohm B, Lundwall A, Malm J: Semenogelins I and II bind zinc and regulate the activity of prostate-specific antigen. Biochem J 2005, 387:447-453.

52. Sturniolo GC, Mestriner $C$, Irato $P$, Albergoni $V$, Longo G, D'Inca R: Zinc therapy increases duodenal concentrations of metallothionein and iron in Wilson's disease patients. Am J Gastroenterol 1999, 94:334-338.

53. Alscher DM, Braun N, Biegger D, Stuelten C, Gawronski K, Mürdter TE, Kuhlmann U, Fritz P: Induction of metallothionein in proximal tubular cells by zinc and its potential as an endogenous antioxidant. Kidney Blood Press Res 2005, 28:127-133.

54. Anastasia MC, Koji I, Yichun Z, Jennifer G, Jorge LY, Hiroshi M: Expression of semenogelins I and II and its prognostic significance in human prostate cancer. Prostate 2011, 71:1108-1114.

doi:10.1186/1471-2490-12-32

Cite this article as: Hadwan et al:: Oral zinc supplementation restore high molecular weight seminal zinc binding protein to normal value in Iraqi infertile men. BMC Urology 2012 12:32.

\section{Submit your next manuscript to BioMed Central and take full advantage of:}

- Convenient online submission

- Thorough peer review

- No space constraints or color figure charges

- Immediate publication on acceptance

- Inclusion in PubMed, CAS, Scopus and Google Scholar

- Research which is freely available for redistribution

Submit your manuscript at www.biomedcentral.com/submit
C) Biomed Central 